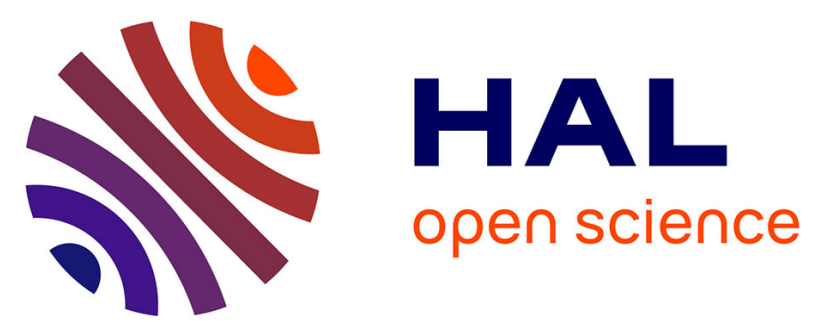

\title{
Influence of process dynamics on the microbial diversity in a nitrifying biofilm reactor: Correlation analysis and simulation study
}

Thomas P.W. Vannecke, Nicolas Bernet, Mari K.H. Winkler, Jean-Philippe

Steyer, Eveline I.P. Volcke

\section{To cite this version:}

Thomas P.W. Vannecke, Nicolas Bernet, Mari K.H. Winkler, Jean-Philippe Steyer, Eveline I.P. Volcke. Influence of process dynamics on the microbial diversity in a nitrifying biofilm reactor: Correlation analysis and simulation study. Biotechnology and Bioengineering, 2016, 113 (9), pp.1962-1974. 10.1002/bit.25952 . hal-02635471

\section{HAL Id: hal-02635471 \\ https://hal.inrae.fr/hal-02635471}

Submitted on 27 May 2020

HAL is a multi-disciplinary open access archive for the deposit and dissemination of scientific research documents, whether they are published or not. The documents may come from teaching and research institutions in France or abroad, or from public or private research centers.
L'archive ouverte pluridisciplinaire HAL, est destinée au dépôt et à la diffusion de documents scientifiques de niveau recherche, publiés ou non, émanant des établissements d'enseignement et de recherche français ou étrangers, des laboratoires publics ou privés.

\section{()ㅜ(1)}

Distributed under a Creative Commons Attribution - NonCommerciall 4.0 International 


\section{Influence of process dynamics on the microbial diversity in a nitrifying biofilm reactor: correlation analysis and simulation study ${ }^{\dagger}$}

T.P.W. Vannecke ${ }^{1}$, N. Bernet $^{2}$, M.K.H. Winkler ${ }^{1,3}$, G. Santa-Catalina ${ }^{2}$, J.-P. Steyer ${ }^{2}$ and E.I.P.

$$
\text { Volcke }^{1 *}
$$

1 Department of Biosystems Engineering, Ghent University, Coupure links 653, 9000 Ghent, BE

2 INRA, UR0050, Laboratoire de Biotechnologie de l'Environnement

F-11100 Narbonne, France

3 Current affiliation: Department of Civil and Environmental Engineering, University of

Washington, Seattle, WA 98195-2700, USA

* Corresponding author

Tel: +32 (0)9 26461 29;

fax: +32 (0)9 2646235

E-mail address: Eveline.Volcke@UGent.be

${ }^{\dagger}$ This article has been accepted for publication and undergone full peer review but has not been through the copyediting, typesetting, pagination and proofreading process, which may lead to differences between this version and the Version of Record. Please cite this article as doi: [10.1002/bit.25952]

Additional Supporting Information may be found in the online version of this article.

This article is protected by copyright. All rights reserved

Received December 3, 2015; Revision Received February 3, 2016; Accepted February 8, 2016

This article is protected by eopyright All rights reserved 


\section{Abstract}

For engineers, it is interesting to gain insight in the effect of control strategies on microbial communities, on their turn influencing the process behaviour and its stability. This contribution assesses the influence of process dynamics on the microbial community in a biofilm reactor for nitrogen removal, which was controlled according to several strategies aiming at nitrite accumulation. The process dataset, combining conventional chemical and physical data with molecular information, was analysed through a correlation analysis and in a simulation study. During nitrate formation, an increased nitrogen loading rate (NLR) resulted in a drop of the bulk liquid oxygen concentration without resulting in nitrite accumulation. A biofilm model was able to reproduce the bulk liquid nitrogen concentrations in two periods before and after this increased NLR. As the microbial parameters calibrated for the ammonia-oxidizing bacteria (AOB) and nitriteoxidizing bacteria (NOB) in both periods were different, it was concluded that the increased NLR governed an AOB and NOB population shift. Based on the molecular data, it was assumed that each period was typified by 1 dominant AOB and probably several subdominant NOB populations. The control strategies for nitrite accumulation influenced the bulk liquid composition by controlling the competition between AOB and NOB. This article is protected by copyright. All rights reserved

\section{Keywords}

Biofilm, Nitrogen removal, Modelling, Dynamics, Microbial diversity, Control

This article is protected by copyright All rights reserved 


\section{Introduction}

The microbial community composition in a reactor does not only influence its performance, but also its stability (Ramirez et al. 2009; Siripong and Rittmann 2007; Wittebolle et al. 2008). Indeed, more diverse systems imply a greater pool of physiological and genetic traits, which provide them with the capacity to interchange and sustain functions under varying environmental conditions (Bellucci et al. 2015). From an engineering point of view, it is interesting to correlate microbial shifts to system performance (Winkler et al. 2013). Moreover, the engineering of wastewater treatment systems would be greatly improved if one also could control the associated microbial diversity (Yuan and Blackall 2002). To achieve this goal, it is required to gain insight in the effect of control strategies on the microbial communities which on their turn influence the process behaviour and/or its stability.

Techniques for biological nitrogen removal from wastewater based on ammonium oxidation to nitrite (nitritation) while preventing further oxidation to nitrate results in significant cost savings over conventional nitrification-denitrification over nitrite (Peng and Zhu 2006; Turk and Mavinic 1986; Verstraete and Philips 1998). Various control strategies have been proposed to promote nitrite accumulation and prevent further nitrate formation, by favouring the ammonia-oxidizing bacteria $(\mathrm{AOB})$ and inhibiting the nitrite-oxidizing bacteria (NOB): (1) $\mathrm{pH}$ control causing inhibition by free ammonia (FA) and free nitrous acid (FNA) of NOB, which is stronger than for AOB (Anthonisen et al. 1976), (2) temperature control in combination with short sludge retention times to washout NOB (Lochtman 1995), as at elevated temperatures, AOB have a higher growth rate than NOB (Wiesmann 1994), and (3) control of the dissolved oxygen (DO) concentration (Bernet et al. 2001; Garrido et al. 1997), as NOB have a lower affinity for oxygen and are hence more sensitive to DO limitation than AOB (Jayamohan et al. 1988). Moreover, biofilm reactors display distinct advantages for the cultivation of the slow growing nitrifiers, due to their specific biomass retention characteristics (Nicolella et al. 2000; Ras et al. 2011; Xu et al. 2015).

Mathematical modeling has become an essential part of biological wastewater treatment (Henze et

This article is protected by copyright All rights reserved nitrifying biofilm reactor: Correlation analysis and simulation study. Biotechnology and 
al. 2000) and is often used for optimization and prediction of process performance, and as a supporting tool for design (Meijer et al. 2002, Lopez-Vazquez et al. 2009). Over the last few years, various studies have illustrated the usefulness of mathematical models to gain process insight and to optimize the performance of biological (nitrogen removal) processes (Hao et al. 2002a\&b ; Volcke et al. 2012). Microbial diversity is typically neglected in conventional models, which at most make a distinction between functional guilds, i.e., AOB and NOB in case of nitrification processes.

Nevertheless, multispecies models including microbial diversity are useful tools to investigate in which way microbial population dynamics are influenced, e.g., by various microbial properties (Vannecke and Volcke, 2015) or biofilm characteristics (Brockmann et al., 2013). They are also essential to study the relation between macroscopic reactor behaviour and microbial population dynamics. Microbial population shifts may result in a different nitrifying performance (Downing and Nerenberg, 2008; Vannecke et al. 2014) but can also be masked by a constant macroscopic reactor behaviour (Vannecke et al. 2015).

In this contribution, the influence of process dynamics on the microbial diversity in a nitrifying biofilm reactor, subjected to different control strategies for nitrite accumulation, is investigated. A unique data set combining both conventional chemical and physical data with molecular information for the nitrification process, and including both new and previously gathered experimental data (Bougard et al. 2006b), is analysed. Through a correlation analysis and a modelling and simulation study insight is gained on the influence of the process dynamics and the control strategies on the microbial diversity and competition in a nitrifying biofilm reactor. Furthermore, the hypothesis that the population shift between Nitrosomonas halophila and Nitrosomonas europaea, observed before the control strategies for nitrite accumulation were implemented, was induced by an increased nitrogen loading rate, was tested.

\section{Materials and methods}

\section{Experimental set-up and operational conditions}

Bougard et al. (2006b) investigated the impact of two control strategies to obtain nitrite accumulation (nitritation) in an inverse turbulent bed reactor (ITBR, Buffiere et al. 2000): (1) high

This article is protected by copyright All rights reserved nitrifying biofilm reactor: Correlation analysis and simulation study. Biotechnology and 
temperature $\left(35^{\circ} \mathrm{C}\right)$ control, in order to increase the free ammonia (FA) concentration and (2) manipulation of the nitrogen loading rate (NLR) through the liquid influent flow $\left(\mathrm{Q}_{\text {in }}\right)$ rate, to keep both the bulk liquid oxygen concentration (DO) and the effluent concentration of ammonium low, following a fuzzy logic control strategy. It should be noted that the objective of the latter strategy was to stimulate the microbial activity rather than the exact regulation of oxygen and/or ammonia concentration to keep a precise set point but (Bougard et al. 2006b). Four membership functions were defined on the oxygen concentration, three on the ammonia concentration and six on the influent flow rate (Supplementary Information, Figure S.1).

Both control strategies led to nitrite accumulation, but the fuzzy logic DO/ammonium controller did not affect the composition of the microbial community, while temperature control did. Besides, a major shift in the nitrifying community of the biofilm reactor took place during the period of nitrate $\left(\mathrm{NO}_{3}{ }^{-}\right)$formation, before the control strategies for nitrite accumulation were implemented:

Nitrosomonas halophila (AOB1) was completely replaced in the biofilm by Nitrosomonas europaea (AOB2) (Bougard et al. 2006b).

The reactor was filled for $20 \%$ of its active volume with solid biocarriers, on which the biomass grew, kept afloat by an upward current of air. The aeration was fixed at a flowrate of $2.88 \mathrm{~m}^{3} \cdot \mathrm{d}^{-1}$. The reactor temperature was maintained at $30{ }^{\circ} \mathrm{C}$ or $35^{\circ} \mathrm{C}$ and the $\mathrm{pH}$ around 7.2.

The experiment was run for 592 days. During continuous operation mode, the reactor was fed with synthetic wastewater, containing around $2000 \mathrm{~g}$ TNH.m ${ }^{-3}$ and $2.82 \cdot 10^{3} \mathrm{~g}$ Viandox.m ${ }^{-3}$ or 583 g COD. $\mathrm{m}^{-3}$ as a carbon source (meat juice), using a conversion factor of $0.207 \mathrm{~g}$ COD.(g Viandox) ${ }^{-1}$ (Bougard 2004). Viandox is composed of components difficult to degrade and was added to the synthetic wastewater to simulate reject water of anaerobic digesters.

During reactor operation, the influent flow rate and the influent ammonium concentration, as well as the bulk liquid ammonium, nitrite and nitrate concentrations were monitored about every two days. Reactor temperature, $\mathrm{pH}$ and bulk liquid oxygen concentration (DO) were monitored online, every two minutes.

This article is protected by copyright All rights reserved nitrifying biofilm reactor: Correlation analysis and simulation study. Biotechnology and 
Further details on the experimental set-up, operational conditions and analytical methods can be found in Bougard et al. (2006b) and Bougard et al. (2006a).

\section{Microbiological and molecular methods}

Molecular information on the bacterial community and ammonia-oxidizing guild published by Bougard et al. (2006b), based on Polymerase Chain Reaction - Single Strand Conformational Polymorphism (PCR-SSCP) combined with the cloning-sequencing technique, were complemented with new, unpublished data on the quantity and microbial diversity of the total bacterial and nitrifying community, based on quantitative PCR (qPCR) and Capillary Electrophoresis-Single Strand Conformation Polymorphism (CE-SSCP), respectively. Samples $(n=30)$ were taken over the experimental period of 592 days during reactor operation. Preparation and storage of the samples, besides DNA extraction was done as reported in Braun et al. (2015).

qPCR of the nitrifying community

The quantity of total Bacteria, AOB and NOB was measured in samples of $5 \mu \mathrm{L}$ diluted DNA taken from the nitrifying ITBR using qPCR-analysis. For the qPCR-analysis of the total bacterial community, the V3 variable region of 16S rRNA genes was amplified from total genomic DNA with the bacterial primers taken from Braun et al. (2015). For AOB, the gene coding for the enzyme ammonia monooxygenase (amoA), the functional gene for oxidation of ammonia to nitrite, was amplified using the forward primer from Kowalchuk et al. (1997), the reverse primer from Hermansson and Lindgren (2001) and the probe from Graham et al. (2007). For NOB, the gene coding for the enzyme nitrite oxidoreductase (nxrA), the functional gene for oxidation of nitrite to nitrate, was amplified using the primers from Wertz et al. (2008). The fluorophores used were Yakima Yellow, FAM and SybrGreen for the total community, AOB and NOB, respectively.

For the total bacterial community, $\mathrm{AOB}$ and $\mathrm{NOB}$, two $\mathrm{C}_{\mathrm{T}}$-values (cycle threshold), defined as the number of cycles required for the fluorescent signal to cross the threshold, were

This article is protected by copyright All rights reserved nitrifying biofilm reactor: Correlation analysis and simulation study. Biotechnology and 
obtained per sample. $\mathrm{C}_{\mathrm{T}}$-levels are inversely proportional to the amount of target nucleic acid in the sample. A standard curve, corresponding to the used fluorophore (Table 1), was generated at each assay, using dilutions of PCR products from known environmental clones (Braun et al. 2015). The amount of total bacterial, AOB and NOB DNA was then calculated based on the standard equation (Eq. 1), and was used to calculate the fraction of $\mathrm{AOB}$ and $\mathrm{NOB}$ in the total bacterial community.

$\log _{10}($ amount $)=\frac{\left(C_{T}-Y_{\text {intercept }}\right)}{\text { slope }}$ Eq. 1

Although a small fraction of heterotrophs, possessing multiple $(>3)$ gene copies of the $16 \mathrm{~S}$ rRNA gene could be present, we can assume that due to the low $\mathrm{C}: \mathrm{N}$ ratio of the influent (0.3) and the low biodegradability of the C-source (Viandox) the biofilm was mainly composed of nitrifiers, as the growth of heterotrophs on decay products can be neglected (Mozumder et al. 2014). Nitrifiers possess 1 copy of the 16S rRNA gene (Stoddard et al. 2015). As the focus was mainly on the relative fractions of $A O B$ and NOB in the biofilm, the correction for gene copy number was not deemed necessary, because both amoA (Norton et al. 2002) and nxrA (Lücker et al. 2010; Poly et al. 2008) can be present in equal (2-3) amounts of gene copies per cell.

\section{CE-SSCP of the nitrifying community}

The total bacterial community in the biofilm was monitored by CE-SSCP as described by Braun et al. (2015). For specific CE-SSCP of the AOB of the $\beta$-subdivision, the total genomic DNA was first amplified with a PCR using specific primers (forward primers CTO189fA/B, CTO189fC and reverse CTO654R) taken from Kowalchuk et al. (1997). Next, the V3 variable region of 16S rRNA genes was amplified from the PCR product using the same procedure as for the total bacterial community. For the specific CE-SSCP of the NOB, nitrite oxydoreductase (nxrA) was amplified (Wertz et al. 2008). The same primers as in Wertz et al. (2008) were used with an additional fluorophore (6-FAM) at the 3' end of the reverse primer.

This article is protected by copyright All rights reserved nitrifying biofilm reactor: Correlation analysis and simulation study. Biotechnology and 
The obtained SSCP profiles, with the number of peaks corresponding to the number of detected bacterial species/strains, were analysed statistically using the StatFingerprints package in R (Braun et al. 2015; Michelland et al. 2009). The Simpson diversity index ( $\left.\mathrm{D}_{\mathrm{SSCP}}\right)$ was calculated for each

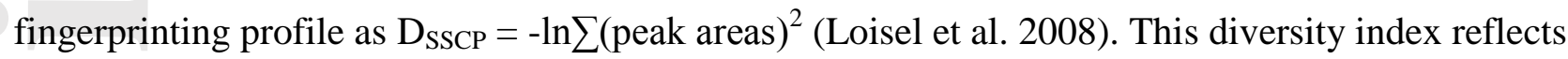
the underlying diversity from the SSCP profile independently of sample size (Rosenzweig 1995): a low and high $\mathrm{D}_{\mathrm{SSCP}}$ depicts a low and high diversity, respectively.

\section{Correlation analysis}

To analyse the large amount of data on the process dynamics and the effect on the microbial dynamics, a correlation analysis was performed in IBM SPSS statistics 22 (Armonk, New York, U.S.). The correlation was expressed using the Pearson product-moment correlation coefficient $r$; $r$ $=1$ indicates total positive correlation, $\mathrm{r}=0$ no correlation, and $\mathrm{r}=-1$ total negative correlation . Only correlations with a p-value smaller than 0.05 were considered significant. The correlation analysis of the physical and chemical data was based on 291 datapoints (290 for DO); the correlation analysis of the microbial community was based on 28 datapoints, as for 2 samples on which molecular data were retrieved, the corresponding physical and chemical data were unavailable.

\section{Modelling the dynamic reactor behaviour}

\section{Reactor model}

A 1-dimensional biofilm model, including biomass variations perpendicular to the carrier on which the considered microorganisms grow, was set up to describe the experimental data of Bougard et al. (2006b) and was implemented in the Aquasim software (Reichert 1994). Growth and decay of $\mathrm{AOB}, \mathrm{NOB}$ and heterotrophs were considered to describe two-step nitrification besides COD removal, based on the model of Mozumder et al. (2014). In contrast to the latter model, anammox was not included in this study and a single state variable was used to describe heterotrophic biomass, while Mozumder et al. (2014) distinguishes 3 state variables for heterotrophic biomass based on the type of electron acceptor used. The model of Mozumder et al. (2014) was further

This article is protected by copyright All rights reserved 
extended with inhibition of AOB and NOB by FA and FNA (Jubany et al. 2009), temperature dependency of growth and decay rates (Hao et al. 2002; Henze et al. 2000), temperature dependency of diffusion (Bernet et al. 2005) and temperature and $\mathrm{pH}$ dependency of the FA:TNH and FNA: $\mathrm{TNO}_{2}$ fractions (Anthonisen et al. 1976).The overall model stoichiometry and kinetics, besides the corresponding parameter values of the developed biofilm model are given in the Supplementary Information (Table S.1, Table S.2 and Table S.3). The microbial characteristics were modelled in a deterministic way, assuming constant values for the microbial parameters (Table S.3.), thus lumping the characteristics of each population. An alternative approach would be to $a$ priori consider a large number of species per functional group, of which the microbial parameters are randomly chosen from a distribution function, thus adding a stochastic component to the model, as in Ramirez et al. (2009). However, since the aim of this study was to follow overall population dynamics, a deterministic approach was preferred.

The model in the current contribution describes biofilm growth on spherical particles with a radius of $73.5 \cdot 10^{-6} \mathrm{~m}$ in an ITBR with constant volume $\left(\mathrm{V}=2.84 \cdot 10^{-3} \mathrm{~m}^{3}\right)$. The total number of particles $\left(2 \cdot 10^{8}\right.$ particles) was calculated based on the total volume of particles $\left(5.68 \cdot 10^{-4} \mathrm{~m}^{3}\right)$ in the reactor and the volume of 1 particle $\left(1.7 \cdot 10^{-12} \mathrm{~m}^{3}\right)$. During the experiments about $80 \%\left(1.6 \cdot 10^{8}\right)$ of the particles were occupied (Bougard 2004). The total amount of biomass of $17 \mathrm{~g}$ VSS or $23 \mathrm{~g}$ COD, using a conversion factor of $0.75 \mathrm{~g} \mathrm{VSS}$.(g COD) $)^{-1}$ (Henze et al. 2000), was assumed to be divided homogenously over the colonized particles, resulting in a steady state thickness of $\mathrm{LF}_{\mathrm{SS}}=20 \cdot 10^{-6}$ m. It was assumed that steady state thickness had already been reached at the start of the simulations, as the experiment was preceded by a start-up period of 22 days.

The biofilm was assumed to be rigid, meaning that particulate components are displaced only by the expansion or shrinkage of the biofilm solid matrix. The biofilm porosity was assumed constant at $80 \%$. An initial active biomass fractioning at the start of Period I of the heterotrophs was set as $0.01 \%$. The remaining active biomass was assumed to be made up by $75 \%$ AOB and $25 \%$ NOB, according to the number of electrons exchanged by the oxidation of $\mathrm{NH}_{4}{ }^{+}$to $\mathrm{NO}_{2}^{-}$and from $\mathrm{NO}_{2}^{-}$to

This article is protected by copyright All rights reserved nitrifying biofilm reactor: Correlation analysis and simulation study. Biotechnology and 
$\mathrm{NO}_{3}{ }^{-}$, respectively.

The influent flow rate (= effluent flow rate), influent ammonium and COD concentration, the temperature of the reactor, $\mathrm{pH}$, and $\mathrm{DO}$ were implemented in the model, using the offline and online monitored data. So, rather than implementing the control strategies as such, controlled and/or manipulated variables were considered as dynamic model inputs, i.e., temperature, DO and liquid flow rate $\left(Q_{\text {in }}\right)$.

\section{Model calibration}

As the focus of this contribution is on the effect of process dynamics on the nitrifying community, no sensitivity analysis was performed but instead it was verified by trial and error whether the simplest possible model was able to simulate the overall reactor behaviour (nitrite versus nitrate accumulation, besides residual ammonium concentration) when only selected microbial parameters were calibrated. The selection of microbial parameters was based on the results of Vannecke and Volcke (2015) (importance of maximum growth rate and affinity for electron donor and acceptor) and Vannecke et al. (2014) (importance of endogenous respiration, in the current contribution replaced by decay).

First, only the microbial parameters of AOB known to have an important effect on bulk liquid composition, i.e., maximum growth rate and affinity for ammonium and oxygen, see Vannecke and Volcke (2015) and previously performed sensitivity analyses (Brockmann et al. 2013; Brockmann and Morgenroth 2007; Brockmann and Morgenroth 2010; Brockmann et al. 2008), were calibrated to the experimentally recorded bulk liquid concentrations of total ammonium (TNH), total nitrite $\left(\mathrm{TNO}_{2}\right)$ and nitrate $\left(\mathrm{NO}_{3}{ }^{-}\right)$. By checking the fit of the simulation results with the observed overall process performance, it was found that besides the calibration of these microbial parameters for the AOB, these parameters also had to be calibrated for the NOB guild. Also FA and FNA inhibition of AOB and NOB had to be implemented in the model and the decay rate and inhibition constants for FA and FNA of both the AOB and the NOB guild had to be calibrated.

This article is protected by copyright All rights reserved nitrifying biofilm reactor: Correlation analysis and simulation study. Biotechnology and 
The values for decay rate, maximum growth rate, the affinity constants and inhibition constants of both the AOB and NOB were estimated by minimizing the sum of the squares of the weighted deviations $\left(\chi^{2}\right)$ between the measurements and the simulation results of the bulk liquid ammonium, nitrite and nitrate concentrations, using the Aquasim software (Reichert et al. 1995). . The sum ( $\left.\chi^{2}\right)$ extends over all the data points of all variables specified as fit targets $\left(\mathrm{TNH}, \mathrm{TNO}_{2}\right.$ and $\left.\mathrm{NO}_{3}{ }^{-}\right)$, which were given equal weights $\left(\chi_{\text {tot }}^{2}=\chi_{\mathrm{TNH}}^{2}+\chi_{\mathrm{TNO} 2}^{2}+\chi_{\mathrm{NO} 3}^{2}\right)$.

The sum was minimized numerically using the secant algorithm (Ralston and Jennrich 1978) and the maximum number of interactions was set at 200 , in order to keep the computational time reasonable. The initial bulk liquid and biofilm concentrations of dissolved substances were assumed to be $0.01 \mathrm{~g} \mathrm{~N} . \mathrm{m}^{-3}$ and the initial biomass concentrations in the biofilm were calculated from the biomass (viable + inerts) density, considering a volume fraction of 0.01 of heterotrophs, 0.1425 of AOB and 0.0475 NOB. The biofilm thickness was assumed to be at steady state and the concentration of particulate inert components in the biofilm was assumed to be $0 \mathrm{~g}$ COD. $\mathrm{m}^{-3}$. When the whole period of reactor operation was calibrated in two separate periods, the initial values of the biofilm thickness, the dissolved (bulk and biofilm) and particulate (biofilm) components of the second period were the last simulation values of the previous period.

The parameter space or constraints concerning the microbial characteristics of AOB and NOB were based on the minimum and maximum values of the range reported in literature. The minimum and maximum values of the ranges for maximum growth rate and affinity constants were taken from Vannecke and Volcke (2015). The minimum and maximum values for decay rates were based on the ranges for maximum growth rate (Vannecke and Volcke, 2015) by defining the decay rate as $5 \%$ of the value for maximum growth rate. A review of inhibition constant values reported in literature was given in this contribution, providing the constraints for the parameter values of the inhibition constants. The starting (uncalibrated) value of all considered microbial parameters was the median value of the corresponding range.

For each simulation, the model accuracy was verified by calculating the Nash-Sutcliffe criterion This article is protected by copyright All rights reserved nitrifying biofilm reactor: Correlation analysis and simulation study. Biotechnology and 
(model efficiency E, see Nash and Sutcliffe,1970) as given in Eq. 2, with $y_{i}^{m}$ the $i^{\text {th }}$ observed value, $\mathrm{y}_{\mathrm{i}}$ the corresponding calculated value and $\bar{y}_{m}$ the mean value of the observations.

$E=1-\frac{\sum_{i=1}^{n}\left(y_{i}^{m}-y_{i}\right)^{2}}{\sum_{i=1}^{n}\left(y_{i}^{m}-\bar{y}_{m}\right)^{2}}$

Eq. 2

Model efficiencies for the fit with bulk liquid concentrations of $\mathrm{TNH}\left(\mathrm{E}_{\mathrm{TNH}}\right), \mathrm{TNO}_{2}\left(\mathrm{E}_{\mathrm{TNO} 2}\right)$ and nitrate $\left(\mathrm{E}_{\mathrm{NO} 3}\right)$ were calculated. If the model efficiency is lower than zero, the observed mean is a better predictor than the model, therefore, the model efficiency should be preferably be larger than 0 and close to the maximum of 1 (perfect fit between simulation and observations).

\section{Simulation set-up}

As the inclusion of diversity within functional guilds is only necessary when the reactor behaviour is clearly influenced by changes in the microbial community (Vannecke et al., 2015), it was attempted to simulate the overall reactor behaviour in terms of bulk liquid concentrations over the whole experimental period with the simplest possible model. To this end, three different simulation approaches were followed (Table 2). Firstly, the model considering 1 AOB, 1 NOB and 1 heterotrophic population, neglecting diversity, was calibrated over the whole experimental period. As the simulation results of this approach (Approach 1) were not in correspondence with the overall reactor behaviour, the model was subsequently calibrated over the two separate periods, period A (day 0 - 100) and period B (day 100 - 592), distinguished by the dominance of Nitrosomonas halophila and Nitrosomonas europaea, respectively (Bougard et al. 2006b) (Approach 2). As the simulation results of Approach 2 better reflected the overall behaviour, the calibrated microbial parameters of both periods were used to construct two AOB and two NOB species which were then implemented in a single model, hereby considering within-guild diversity (Approach 3).

\section{Results and discussion \\ Correlation analysis}

\section{Chemical and physical data}

Four operational periods could be distinguished (Table 3 ):period I (day 0 - 113) was typified with a

This article is protected by copyright All rights reserved 
temperature of $30^{\circ} \mathrm{C}$ and nitrate formation, period II (day 114 - 230) with temperature control to $35^{\circ} \mathrm{C}$ and nitrite accumulation, period III (day $231-491$ ) with a temperature of $30^{\circ} \mathrm{C}$ and recovery to full nitrification (nitrate formation) by lowering the NLR and period IV (day 492-592) with a temperature of $30^{\circ} \mathrm{C}$ and fuzzy logic DO/ammonium control to achieve nitrite accumulation. An overview of the operational conditions during reactor operation is given in the Supplementary Information (Figure S.2).

Figure 1 displays the bulk liquid total ammonium $(\mathrm{TNH})$, total nitrite $\left(\mathrm{TNO}_{2}\right)$ and nitrate concentrations (Figure 1A) and the corresponding bulk liquid FA and FNA concentrations (Figure 1B), calculated from the total ammonium and total nitrite concentrations, considering the reactor temperature and $\mathrm{pH}$ (Anthonisen et al. 1976). Table 4 summarizes the results of the correlation analysis of the chemical and physical data.

The strongest significant correlation observed for temperature, was the negative correlation with nitrate $(r=-0.39, \mathrm{p}<0.05$, Table 4$)$, confirming the lower production of nitrate at higher temperature, which was the basis for the temperature control strategy applied in Period II (Table 4).

The oxygen concentration in the bulk liquid was negatively correlated with the total ammonium concentration in the bulk liquid $(r=-0.21, \mathrm{p}<0.05$, Table 4$)$ and with the nitrogen loading rate $(\mathrm{r}=-0.45, \mathrm{p}<0.05$, Table 4). An increasing NLR and bulk liquid concentration of total ammonium thus result in a decreasing bulk liquid oxygen concentration for the prevailing fixed aeration flow rate, due to the increasing biological activity and oxygen consumption of the nitrifiers.

The FA concentration increased $(r=0.74, \mathrm{p}<0.05)$ and the FNA concentration decreased $(r=-0.29$, $\mathrm{p}<0.05$ ) with increasing $\mathrm{pH}$ (Table 4), following the expected patterns (Anthonisen et al. 1976). The strong correlation indicates that small deviations from the $\mathrm{pH}$ set-point (see Supplementary Information, Figure S.2) could have large effects on the FA and FNA concentration. The concentrations of FA and FNA observed in the bulk liquid were equal to or even higher than the median value of the reported FA inhibition constants for NOB and FNA inhibition constants for

This article is protected by copyright All rights reserved nitrifying biofilm reactor: Correlation analysis and simulation study. Biotechnology and 
$\mathrm{AOB}$ and NOB (Figure 2), indicating possible inhibition of the NOB by FA and the AOB and NOB by FNA.

Overall, from the correlation analysis of the physical and chemical data, it was concluded that temperature, $\mathrm{DO}$ and nitrogen loading rate, besides $\mathrm{pH}$, had a large influence on the bulk liquid concentration of the different nitrogen compounds and thus constituted suitable control handles for process operation.

\section{Microbial community information}

The fraction of $\mathrm{AOB}$ and $\mathrm{NOB}$ in the biofilm (qPCR) and the diversity of the total and nitrifying community (CE-SSCP) are summarised in Figure 1C and Figure 1D, respectively. In Table 5, the correlation analysis considering the microbial community related to the chemical and physical data is given.

The fraction of $\mathrm{AOB}$ was positively correlated $(\mathrm{r}=0.63, \mathrm{p}<0.05)$ with the total nitrite concentrations and the fraction of NOB was correlated negatively $(r=-0.78, p<0.05)$ with the nitrite concentration and positively $(r=0.72, \mathrm{p}<0.05)$ with the nitrate concentration (Table 5). This indicates that the qPCR analysis based on the amoA and nxrA genes correctly targeted the AOB and the NOB, respectively.

The overall fraction of AOB $(28 \pm 21.86 \%)$ was higher than the fraction of NOB $(0.84 \pm 0.82 \%)$ in the biofilm (Figure 1C), as expected from the yield differences in AOB and NOB (Winkler et al. 2012).

Logically, the fraction of NOB decreased in the periods of nitrite accumulation (Table 3), reaching a minimum of $0.04 \%$ during period III (Figure 1C). This low NOB content explains why it took so long before the system could reach again complete conversion of ammonium to nitrate in period III (Table 3). The nitrogen loading rate had to be reduced several times (see Supplementary

Information, Figure S.2) to relax the inhibitory conditions and oxygen limitation, in order to allow NOB growth in the biofilm and get the system back to full nitrification, which was necessary to test

This article is protected by copyright All rights reserved nitrifying biofilm reactor: Correlation analysis and simulation study. Biotechnology and 
an alternative control strategy for nitrite accumulation in Period IV. Elawwad et al. (2013) showed that $\mathrm{NOB}$ are indeed more sensitive than $\mathrm{AOB}$ to starvation and require longer periods for complete recovery.

Although diversity was calculated from SSCP profiles and only strong tendencies can be significant, some trends were visible (Figure 1D). The diversity of the total community was maximal at day $4\left(\mathrm{D}_{\mathrm{SSCP}}=4.18\right)$, declined to its minimum $\left(\mathrm{D}_{\mathrm{SSCP}}=2.34\right)$ during Period III $($ Figure 1D) and was negatively correlated with total nitrite $(r=-0.45, p<0.05)$ and FNA $(r=-0.48, p<0.05)$ concentrations, which shows total diversity decreased when nitrite accumulated. The diversity of the total community $\left(\mathrm{D}_{\mathrm{SSCP}}=3.29 \pm 0.45\right)$ resembled the diversity of the $\mathrm{NOB}\left(\mathrm{D}_{\mathrm{SSCP}}=3.17 \pm\right.$ $0.66)$, while the $\mathrm{AOB}$ diversity $\left(\mathrm{D}_{\mathrm{SSCP}}=1.30 \pm 0.35\right)$ was clearly lower (Figure $\left.1 \mathrm{D}\right)$. The fraction of AOB and NOB were indeed negatively $(r=-0.39, p<0.05)$ and positively $(r=0.53, p<0.05)$ correlated with the total diversity, respectively (Table 5). These observations indicate that the NOB diversity was higher than the AOB diversity.

The highest AOB diversity $\left(\mathrm{D}_{\mathrm{SSCP}} \approx 2\right)$ was observed in period I around day 77 (Figure 1D), which corresponds with the coexistence of Nitrosomonas halophila and Nitrosomonas europaea in the biofilm reported by Bougard et al. (2006b). When Nitrosomonas europaea was the only AOB in the biofilm from day 100 , the $\mathrm{D}_{\mathrm{SSCP}}$ value declined to 1 .

The NOB diversity reached its lowest value $\left(\mathrm{D}_{\mathrm{SSCP}}=1.90\right)$ during Period II (Figure 1D), when the reactor was submitted to temperature control (Table 3).High NOB diversity (up to $\mathrm{D}_{\mathrm{SSCP}}=4.21$ ) was observed during Period IV, when fuzzy logic DO/ammonium control was applied by adjusting the influent flow rate (Table 3). This is in agreement with the conclusion of Bougard et al. (2006b) that, although both control strategies resulted in nitrite accumulation, the fuzzy logic DO/ammonium controller in Period IV maintained the microbial diversity better than temperature control. The design of this controller was indeed intended (1) good enough to accumulate steadily nitrite within the reactor but (2) bad enough to maintain the microbial diversity (Bougard et al. 2006b). Maintaining overall microbial diversity is important to ensure reactor performance and This article is protected by copyright All rights reserved nitrifying biofilm reactor: Correlation analysis and simulation study. Biotechnology and 
process stability on the long term, e.g., when facing disturbances (Daims et al. 2001; Egli et al. 2003; Ramirez et al. 2009) and/or to allow operational flexibility, e.g., when the decision is taken to go back to full nitrification after nitrite accumulation (Bougard et al. 2006b).

\section{Modelling the dynamic reactor behaviour}

\section{Approach 1: Conventional model (1 $\mathrm{AOB}$ and $1 \mathrm{NOB})$ for whole period}

Preliminary simulations had shown that, to reflect the overall dynamic reactor behaviour, i.e., nitrite accumulation or nitrate formation besides residual ammonium bulk liquid concentration, the microbial parameters of both AOB and NOB had to be calibrated. Furthermore, based on the literature study on FA and FNA inhibition of AOB and NOB (Figure 2), it was concluded that the FA and FNA concentrations reached were possibly inhibitory for both AOB and NOB. Therefore, FA and FNA inhibition were taken up in the model following Jubany et al. (2009). The maximum growth rate, decay rate, affinity for electron donor and acceptor and inhibition constants for FA and FNA inhibition were estimated for AOB and NOB by minimizing the sum of the squares of the weighed difference $\left(\chi^{2}\right)$ between experimental data and simulation results of the bulk liquid total ammonium $(\mathrm{TNH})$, total nitrite $\left(\mathrm{TNO}_{2}\right)$ and nitrate concentration,

First, it was attempted to simulate the macroscale dynamics by calibrating a single AOB and a single NOB population (Approach 1), each characterized by lumped parameter values reflecting the mean behaviour of their functional guild, as is common practice in nitrification process models. Even for the best possible fit ( $\chi_{\text {tot }}^{2}: 2197 ; \chi^{2}{ }_{\mathrm{TNH}}: 1291 ; \chi^{2} \mathrm{TNO}_{2}: 419 ; \chi^{2} \mathrm{NO}_{3}: 487$, see Figure $\left.3 \mathrm{~A}\right)$, the overall dynamics were not simulated correctly: nitrite accumulated during the simulation of Period III (Table 3), while in this period the system was brought back from nitrite to nitrate accumulation by lowering the NLR (Table 3). The model efficiencies considering total ammonium $\left(\mathrm{E}_{\mathrm{TNH}}=-2.98\right)$, total nitrite $\left(\mathrm{E}_{\mathrm{TNO} 2}=-0.29\right)$ and nitrate $\left(\mathrm{E}_{\mathrm{NO} 3}=-0.50\right)$ were all negative. In conclusion, it was not possible to simulate the whole experimental period with a single AOB and a single NOB population. This indicates that one or more significant population shifts had taken place during the whole experimental period.

This article is protected by copyright All rights reserved nitrifying biofilm reactor: Correlation analysis and simulation study. Biotechnology and 
Approach 2: Conventional model (1 $\mathrm{AOB}$ and $1 \mathrm{NOB}$ ) distinguishing two periods

As it was not possible to simulate the whole experimental period with a single AOB and a single NOB population, the experimental dataset was split up into the two periods i.e. Period A $(0-100$ days) and Period B (100 - 592 days)dominated by two different AOB species: Nitrosomonas halophila and Nitrosomonas europaea, respectively. The model was then calibrated individually for these periods and the relative changes of the parameter values over these two periods were verified. The process performance $\left(\chi^{2}\right.$ tot $\left.=1334\right)$ was better reflected when the model was calibrated for Period A $\left(\chi_{\text {tot_A }}^{2}: 254 ; \chi^{2} \mathrm{TNH}_{0}: 63 ; \chi^{2}{ }_{\mathrm{TNO} 2}: 109 ; \chi^{2}{ }_{\mathrm{NO} O}: 82\right)$ and Period B $\left(\chi_{\text {tot_B }}^{2}: 1080 ; \chi^{2}{ }_{\mathrm{TNH}}: 693\right.$; $\left.\chi^{2}{ }_{\mathrm{TNO} 2}: 168 ; \chi^{2}{ }_{\mathrm{NO}}: 219\right)$ separately (Approach 2, Figures 3B and 3C). Although the Nash Sutcliffe criterion was negative for total ammonium $\left(\mathrm{E}_{\mathrm{TNH}}=-0.11\right)$, total nitrite $\left(\mathrm{E}_{\mathrm{TNO} 2}=-0.91\right)$ and nitrate $\left(\mathrm{E}_{\mathrm{NO} 3}=-0.43\right)$ in Period $\mathrm{A}$ and for total ammonium $\left(\mathrm{E}_{\mathrm{TNH}}=-1.61\right)$ in Period $\mathrm{B}$, the model efficiencies obtained were generally larger than for Approach1. The model efficiencies for total nitrite $\left(\mathrm{E}_{\mathrm{TNO} 2}=0.37\right)$ and nitrate in Period $\mathrm{B}\left(\mathrm{E}_{\mathrm{NO} 3}=0.18\right)$ were positive even though quite low, due to the large variability of the dataset. Visual inspection (Figures 3B and 3C) confirmed that, following Approach 2, the model reflected the overall reactor behaviour better It was concluded that, to reflect the experimental observations, (at least) two periods had to be distinguished for model calibration: Period A (0-100 days) and Period B (100-592 days). These periods were based on the AOB population shift observed by Bougard et al. (2006b): in Period A, Nitrosomonas halophila was the dominant $\mathrm{AOB}$, while in Period B, this species was completely replaced by Nitrosomonas europaea. The CE-SSCP data described in this study indicated that the AOB diversity was indeed the highest when both AOB coexisted, around day 50.

The calibrated microbial parameters of both AOB and NOB were different for both periods (Table 6). This indicates that besides the AOB shift, also changes in the NOB guild had taken place around day 100. Although identification of the dominant bacterial peaks of the SSCP profiles using the cloning-sequencing technique revealed no NOB, neither a NOB shift (Bougard et al. 2006b), it is possible that besides the visible AOB shift, also undetected microbial community changes were

This article is protected by copyright All rights reserved nitrifying biofilm reactor: Correlation analysis and simulation study. Biotechnology and 
occurring in the NOB guild.

The oxygen affinity constant of AOB clearly differed between Period A and Period B (Table 6). In Period A, the AOB guild is typified by a high oxygen affinity $\left(\mathrm{K}_{\mathrm{O} 2}^{\mathrm{AOB}}=0.078 \mathrm{~g} \mathrm{O}_{2} \cdot \mathrm{m}^{-3}\right)$ and a low maximum growth rate $\left(\mu_{\max }^{\mathrm{AOB}}=0.65 \mathrm{~d}^{-1}\right)$; in Period $\mathrm{B}$ by a lower oxygen affinity (higher $\mathrm{K}_{\mathrm{O} 2}^{\mathrm{AOB}}=$ $\left.0.71 \mathrm{~g} \mathrm{O}_{2} \cdot \mathrm{m}^{-3}\right)$ and a higher maximum growth rate $\left(\mu_{\max }^{\mathrm{AOB}}=0.71 \mathrm{~d}^{-1}\right)$. This indicates that the drop of DO concentrations to very low values (between $0.3-0.7 \mathrm{~g} \mathrm{O}_{2} \cdot \mathrm{m}^{-3}$ ) at the end of period I (Table 3), following an increase of the NLR (see Supplementary Information, Figure S.2), governed the observed AOB population shift from Nitrosomonas halophila to Nitrosomonas europaea, following the K- and r-strategy theory (Andrews and Harris 1986) concerning oxygen, respectively. The observed diversity of AOB (Figure 1D) was very low and declined further after Nitrosomonas halophila was washed out of the biofilm. It can thus be concluded that the calibrated microbial parameters for the AOB probably correspond with the observed species, i.e. Nitrosomonas halophila, dominant during the most of Period A and Nitrosomonas europaea, dominant during Period B.

The NOB community also changed between the two periods. Just as for the AOB, the oxygen affinity of the NOB decreased from Period $\mathrm{A}\left(\mathrm{K}_{\mathrm{O} 2}^{\mathrm{NOB}}=0.049 \mathrm{~g} \mathrm{O}_{2} \cdot \mathrm{m}^{-3}\right)$ to Period $\mathrm{B}\left(\mathrm{K}_{\mathrm{O} 2}^{\mathrm{NOB}}=0.06\right.$ $\left.\mathrm{g} \mathrm{O}_{2} \cdot \mathrm{m}^{-3}\right)$. However, the maximum growth rate of NOB decreased from period $\mathrm{A}\left(\mu_{\max }^{\mathrm{NOB}}=1.43\right.$ $\left.\mathrm{d}^{-1}\right)\left(\right.$ to Period $\mathrm{B}\left(\mu_{\max }^{\mathrm{NOB}}=0.30 \mathrm{~d}^{-1}\right)$, in contrast to the one of AOB. The NOB guild in period A being typified by a high growth rate $\left(1.43 \mathrm{~d}^{-1}\right)$ and a high affinity for oxygen $\left(0.049 \mathrm{~g} \mathrm{O}_{2} \cdot \mathrm{m}^{-3}\right)$ does not exclude that several subdominant species of NOB, both r-strategists (high growth rate) and Kstrategists (high oxygen affinity), were present in very low concentrations. The coexistence of several subdominant NOB species was judged likely from the high diversity of NOB expected based on the similarity of the NOB and total bacterial community diversity (Figure 1D) and the decrease of the total bacterial community diversity when NOB were washed out (Table 5).

Furthermore, the coexistence of different NOB species had been observed before in biofilms (Downing and Nerenberg 2008; Gieseke et al. 2003; Schramm et al. 1998). Therefore, the calibrated This article is protected by copyright All rights reserved nitrifying biofilm reactor: Correlation analysis and simulation study. Biotechnology and 
microbial parameters for Period A and Period B probably represented lumped parameters for different NOB populations originating from two different NOB guilds rather than from two different NOB species.

The reactor nitrogen concentrations in Period B could be simulated (Figure 3C) through a model with $1 \mathrm{AOB}$ and $1 \mathrm{NOB}$, neglecting diversity. This indicates that the applied control strategies for nitrite accumulation, i.e., temperature control and fuzzy logic DO/ammonium control, influenced the microbial community mainly on the level of guilds (AOB and NOB), as confirmed by the qPCR analysis. Possible changes in microbial diversity or population shifts within Period B as indicated by the CE-SSCP analysis, i.e. low NOB diversity during temperature control and higher NOB diversity during DO/ammonium fuzzy logic control, , did not influence the reactor behaviour instantaneously. Model extension with within-guild diversity is only necessary when the reactor behaviour is clearly influenced by changes in the microbial community (Vannecke et al. 2015). Nevertheless, these unnoticed changes in microbial composition and diversity of the (nitrifying) community may have important effects on the reactor performance and process stability on the long term, e.g., when facing disturbances (Daims et al. 2001; Egli et al. 2003; Ramirez et al. 2009) and/or to allow operational flexibility (Bougard et al. 2006b).

No concentration profiles could be observed in the biofilm. The steady state biofilm thickness was indeed very small, reducing the effect of internal mass transfer limitation, similar to the observations in Vannecke et al. (2014) for the same biofilm reactor type. The relatively high NOB diversity observed probably did not result from niche separation due to diffusional substrate gradients but rather from a non-uniform biomass distribution over the particles : some particles will be covered with a very thin biofilm while others are covered with a thicker biofilm, allowing different species to occupy different niches.

This article is protected by copyright All rights reserved nitrifying biofilm reactor: Correlation analysis and simulation study. Biotechnology and 
Approach 3: Model including within-guild diversity (2 AOB and 2 NOB) for whole period

As Period A and Period B could be described individually by a single AOB and a single NOB species (see Table 6 for their characteristics), these two AOB and two NOB populations, , were integrated in a single model also containing 1 heterotrophic population.

However, it was not possible to calibrate the resulting model in terms of the bulk liquid concentrations of ammonium, nitrite and nitrate over the complete experimental period of 592 days (Supplementary Information, Figure S.3). The model predicted nitrate accumulation for the whole experimental period; the overall fit of the simulation results for bulk liquid nitrogen concentrations was very low $\left(\chi_{\text {tot }}^{2}=3204\right)$; the model efficiencies for total ammonium $\left(\mathrm{E}_{\mathrm{TNH}}=-0.44\right)$, total nitrite $\left(\mathrm{E}_{\mathrm{TNO} 2}=-1.26\right)$ and especially for nitrate $\left(\mathrm{E}_{\mathrm{NO} 3}=-5.19\right)$ were negative.

As for the microbial community composition, the AOB and NOB species of Period A remained dominant also during Period B, while the AOB and NOB species of Period B should become dominant after 100 days. The species of period B did not survive the severe DO drop from day 50 onwards (see Figure S.2 in the Supplementary Information), due to their lower affinity for oxygen than the species from Period A. In the real system, the species of Period B could have invaded the system by attachment from the bulk liquid, while in the model attachment was neglected and the influent was assumed to contain no bacterial species. Alternatively, the populations of Period A could have been acclimated to the conditions in Period B, which also can result in changed parameter values. Furthermore, as calibrated parameters such as the affinity constants may describe apparent features, lumping other phenomena such as diffusion (Arnaldos et al. 2015), these phenomena may have been changing over the experimental period.

\section{Conclusions}

The influence of process dynamics on the nitrifying microbial community in a biofilm reactor controlled for nitrite accumulation, was analysed.

- The correlation analysis confirmed that temperature, $\mathrm{pH}$, bulk liquid oxygen concentration and nitrogen loading rate all constitute suitable control handles for process operation in

This article is protected by copyright All rights reserved nitrifying biofilm reactor: Correlation analysis and simulation study. Biotechnology and 
terms of nitrogen conversion.

- The experimental observations could only be described with a model considering a single (lumped) AOB and a single NOB, besides a single heterotrophic population, when the microbial parameters for AOB and NOB were calibrated separately for two operating periods resulting from an increased nitrogen loading rate and associated drop in the bulk liquid oxygen concentration. This indicated a change of the AOB and NOB guild.

- The diversity of the total bacterial community resembled the diversity of the NOB, while the diversity of the AOB was much lower. A large number of small, subdominant NOB populations was presumably present in the biofilm. The calibrated AOB parameter values for the two different periods correspond with two different AOB species (Nitrosomonas halophila and Nitrosomonas europaea), while the NOB parameters represent two different NOB guilds.

- As revealed through CE-SSCP analysis, the two different control strategies for nitrite accumulation influenced the microbial diversity. As modelling microbial diversity was unnecessary to reproduce the reactor performance during the period in which both control strategies were applied, the changes in diversity did not influence the reactor performance instantaneously. However, one cannot exclude that such changes in diversity influence the reactor performance and process stability in the long term.

\section{Acknowledgements}

Thomas Vannecke was supported by the Research Foundation-Flanders (FWO) through a Ph.D. fellowship. The collaboration between the Biosystems Engineering Department (UGent, Belgium) and the LBE-INRA (France) was supported by the Tournesol Project T2013.03). Mari Winkler was funded by a Marie Curie Intra-European Fellowship (PIEF-GA-2012-329328).

This article is protected by copyright All rights reserved 


\section{References}

Andrews JH, Harris RF. 1986. R-selection and K-selection and microbial ecology. Adv Microbial Ecol 9:99-147.

Anthonisen AC, Loehr RC, Prakasam TBS, Srinath EG. 1976. Inhibition of nitrification by ammonia and nitrous acid. Journal WPCF 48(5):835-852.

Arnaldos M, Amerlinck Y, Rehman U, Maere T, Van Hoey S, Naessens W, Nopens I. 2015. From the affinity constant to the half-saturation index: Understanding conventional modeling concepts in novel wastewater treatment processes. Water Res 70:458-470.

Bellucci M, Ofiteru ID, Beneduce L, Graham DW, Head IM, Curtis TP. 2015. A preliminary and qualitative study of resource ratio theory to nitrifying labscale bioreactors. Microb Biotechnol 8(3):590-603.

Bernet N, Dangcong P, Delgenès J, Moletta R. 2001. Nitrification at low oxygen concentration in biofilm reactor. J Environ Eng 127(3):266-271.

Bernet N, Sanchez O, Cesbron D, Steyer JP, Delgenes JP. 2005. Modeling and control of nitrite accumulation in a nitrifying biofilm reactor. Biochem Eng J 24(2):173-183.

Bougard D. 2004. Traitement biologique d'effluents azotés avec arrêt de la nitrification au stade nitrite. $\mathrm{PhD}$ thesis Ecole nationale superieure agronomique de Montpellier, $234 \mathrm{p}$.

Bougard D, Bernet N, Cheneby D, Delgenes JP. 2006a. Nitrification of a high-strength wastewater in an inverse turbulent bed reactor: Effect of temperature on nitrite accumulation. Process Biochem41(1):106-113.

Bougard D, Bernet N, Dabert P, Delgenes JP, Steyer JP. 2006b. Influence of closed loop control on microbial diversity in a nitrification process. Water Sci Technol 53(4-5):85-93.

Braun F, Hamelin J, Bonnafous A, Delgenès N, Steyer J-P, Patureau D. 2015. Similar PAH fate in anaerobic digesters inoculated with three microbial communities accumulating either volatile fatty acids or methane. PLoS One 10(4).

Brockmann D, Caylet A, Escudié R, Steyer JP, Bernet N. 2013. Biofilm model calibration and microbial diversity study using Monte Carlo simulations. Biotechnol Bioeng 110(5):1323-1332.

Brockmann D, Morgenroth E. 2007. Comparing global sensitivity analysis for a biofilm model for two-step nitrification using the qualitative screening method of Morris or the quantitative variance-based Fourier Amplitude Sensitivity. Water Sci Technol 56(8):85-94.

Brockmann D, Morgenroth E. 2010. Evaluating operating conditions for outcompeting nitrite oxidizers and maintaining partial nitrification in biofilm systems using biofilm modeling and Monte Carlo filtering. Water Res 44(6):1995-2009.

This article is protected by copyright All rights reserved nitrifying biofilm reactor: Correlation analysis and simulation study. Biotechnology and 
Brockmann D, Rosenwinkel KH, Morgenroth E. 2008. Practical identifiability of biokinetic parameters of a model describing two-step nitrification in biofilms. Biotechnol Bioeng 101(3):497-514.

Buffiere P, Bergeon JP, Moletta R. 2000. The inverse turbulent bed: a novel bioreactor for anaerobic treatment. Water Res 34(2):673-677.

Daims H, Purkhold U, Bjerrum L, Arnold E, Wilderer PA, Wagner M. 2001. Nitrification in sequencing biofilm batch reactors: lessons from molecular approaches. Water Sci Technol 43(3):9-18.

Downing LS, Nerenberg R. 2008. Effect of oxygen gradients on the activity and microbial community structure of a nitrifying, membrane-aerated biofilm. Biotechnol Bioeng 101(6):11931204.

Egli K, Langer C, Siegrist H-R, Zehnder AJB, Wagner M, van der Meer JR. 2003. Community analysis of ammonia and nitrite oxidizers during start-up of nitritation reactors. Appl Environ Microbiol 69(6):3213-3222.

Elawwad A, Sandner H, Kappelmeyer U, Koeser H. 2013. Long-term starvation and subsequent recovery of nitrifiers in aerated submerged fixed-bed biofilm reactors. Environ Technol 34(8):945-959.

Garrido JM, van Benthum WAJ, van Loosdrecht MCM, Heijnen JJ. 1997. Influence of dissolved oxygen concentration on nitrite accumulation in a biofilm airlift suspension reactor. Biotechnol Bioeng 53(2):168-178.

Gieseke A, Bjerrum L, Wagner M, Amann R. 2003. Structure and activity of multiple nitrifying bacterial populations co-existing in a biofilm. Environ Microbiol 5(5):355-369.

Graham DW, Knapp CW, Van Vleck ES, Bloor K, Lane TB, Graham CE. 2007. Experimental demonstration of chaotic instability in biological nitrification. The ISME journal 1(5):385-393.

Hao XD, Heijnen JJ, van Loosdrecht MCM. 2002a. Model-based evaluation of temperature and inflow variations on a partial nitrification-ANAMMOX biofilm process. Water Res 36(19):48394849.

Hao XD, Heijnen JJ, van Loosdrecht MCM. 2002b. Sensitivity analysis of a biofilm model describing a one-stage completely autotrophic nitrogen removal (CANON) process. Biotechnol Bioeng 77(3):266-277.

Henze M, Gujer W, Mino T, van Loosdrecht MCM. 2000. Activated sludge models ASM1, ASM2, ASM2d and ASM3. IWA Scientific and Technical Report No. 9. IWA Task Group on Mathematical Modelling for Design and Operation of Biological Wastewater Treatment. London: IWA Publishing.

This article is protected by copyright All rights reserved nitrifying biofilm reactor: Correlation analysis and simulation study. Biotechnology and 
Hermansson A, Lindgren P-E. 2001. Quantification of ammonia-oxidizing bacteria in arable soil by real-time PCR. Appl Environ Microbiol 67(2):972-976.

Jayamohan S, Ohgaki S, Hanaki K. 1988. Effect of DO on kinetics of nitrification. Water Supply: the review journal of the international water supply association 6(3):141-150.

Jubany I, Lafuente J, Baeza JA, Carrera J. 2009. Total and stable washout of nitrite oxidizing bacteria from a nitrifying continuous activated sludge system using automatic control based on Oxygen Uptake Rate measurements. Water Res 43(11):2761-2772.

Kowalchuk GA, Stephen JR, De Boer W, Prosser JI, Embley TM, Woldendorp JW. 1997. Analysis of ammonia-oxidizing bacteria of the beta subdivision of the class Proteobacteria in coastal sand dunes by denaturing gradient gel electrophoresis and sequencing of PCR-amplified 16S ribosomal DNA fragments. Appl Environ Microbiol63(4):1489-1497.

Lochtman SFW. 1995. Proceskeuze en -optimalisatie van het SHARON proces voor slibverwerkingsbedrijf Sluisjesdijk (Process choice and optimisation of the SHARON process for the sludge treatment plant Sluisjesdijk). BODL report: TU Delft.

Loisel P, Haegeman B, Hamelin J, Harmand J, Godon J-J; 2008 2008-10-22. A method for measuring the biological diversity of a sample. France.

Lopez-Vazquez, C. M., A. Oehmen, C. M. Hooijmans, D. Brdjanovic, H. J. Gijzen, Z. Yuan, and M. C. M. van Loosdrecht. 2009. Modeling the PAO-GAO competition: Effects of carbon source, pH and temperature. Water Res. 43:450-462.

Lücker S, Wagner M, Maixner F, Pelletier E, Koch H, Vacherie B, Rattei T, Damsté JSS, Spieck E, Le Paslier D and others. 2010. A Nitrospira metagenome illuminates the physiology and evolution of globally important nitrite-oxidizing bacteria. PNAS 107(30):13479-13484.

Meijer, S., M. van Loosdrecht, and J. Heijnen. 2002. Modelling the start-up of a full-scale biological nitrogen and phosphorus removing WWTP's. . Water Res. 6:4667-4682.

Michelland RJ, Dejean S, Combes S, Fortun-Lamothe L, Cauquil L. 2009. StatFingerprints: a friendly graphical interface program for processing and analysis of microbial fingerprint profiles. Mol Ecol Resour 9(5):1359-1363.

Mozumder MSI, Picioreanu C, van Loosdrecht MCM, Volcke EIP. 2014. Effect of heterotrophic growth on autotrophic nitrogen removal in a granular sludge reactor. Environ Technol 35(8):1027-1037.

Nash J, Sutcliffe JV. 1970. River flow forecasting through conceptual models part I-A discussion of principles. J Hydrol 10(3):282-290.

Nicolella C, van Loosdrecht MCM, Heijnen JJ. 2000. Wastewater treatment with particulate biofilm reactors. J Biotechnol 80(1):1-33.

This article is protected by copyright All rights reserved nitrifying biofilm reactor: Correlation analysis and simulation study. Biotechnology and 
Norton JM, Alzerreca JJ, Suwa Y, Klotz MG. 2002. Diversity of ammonia monooxygenase operon in autotrophic ammonia-oxidizing bacteria. ArchMicrobiol 177(2):139-149.

Peng YZ, Zhu G. 2006. Biological nitrogen removal with nitrification and denitrification via nitrite pathway. Appl Microbiol Biotechnol 73(1):15-26.

Poly F, Wertz S, Brothier E, Degrange V. 2008. First exploration of Nitrobacter diversity in soils by a PCR cloning-sequencing approach targeting functional gene nxrA. FEMS Microbiol Ecol 63(1):132-140.

Ralston ML, Jennrich RI. 1978. DUD, A derivative-free algorithm for nonlinear least squares. Technometrics 20(1):7-14.

Ramirez I, Volcke EIP, Rajinikanth R, Steyer JP. 2009. Modeling microbial diversity in anaerobic digestion through an extended ADM1 model. Water Res 43(11):2787-2800.

Ras M, Lefebvre D, Derlon N, Paul E, Girbal-Neuhauser E. 2011. Extracellular polymeric substances diversity of biofilms grown under contrasted environmental conditions. Water Res 45(4):1529-38.

Reichert P. 1994. Aquasim - a tool for simulation and data-analysis of aquatic systems. Water Sci Technol 30(2):21-30.

Reichert P, von Schulthess R, Wild D. 1995. The use of AQUASIM for estimating parameters of activated sludge models. Water Sci Technol 31(2):135-147.

Rosenzweig ML. 1995. Species diversity in space and time: Cambridge University Press. 436 p.

Schramm A, de Beer D, Wagner M, Amann R. 1998. Identification and activities in situ of Nitrosospira and Nitrospira spp. as dominant populations in a nitrifying fluidized bed reactor. Appl Environ Microbiol 64(9):3480-3485.

Siripong S, Rittmann BE. 2007. Diversity study of nitrifying bacteria in full-scale municipal wastewater treatment plants. Water Res 41(5):1110-1120.

Stoddard SF, Smith BJ, Hein R, Roller BRK, Schmidt TM. 2015. rrnDB: improved tools for interpreting rRNA gene abundance in bacteria and archaea and a new foundation for future development. Nucleic Acids Res 43(D1):D593-D598.

Turk O, Mavinic D. 1986. Preliminary assessment of a shortcut in nitrogen removal from wastewater. Can J Civ Eng 13(6):600-605.

Vannecke TPW, Bernet N, Steyer JP, Volcke EIP. 2014. Modelling ammonium-oxidizing population shifts in a biofilm reactor. Water Sci Technol 69(1):208-16.

Vannecke TPW, Volcke EIP. 2015. Modelling microbial competition in nitrifying biofilm reactors. Biotechnol Bioeng 112(12):2550-2561.

This article is protected by copyright All rights reserved Vannecke, T. P., Bernet, N., Winkler, M. K., Santa-Catalina, G., Steyer, J.-P., Volcke, E. I. nitrifying biofilm reactor: Correlation analysis and simulation study. Biotechnology and 
Vannecke TPW, Wells G, Hubaux N, Morgenroth E, Volcke EIP. 2015. Considering microbial and aggregate heterogeneity in biofilm reactor models: How far do we need to go? Water Sci Technol 72(10):1692-1699.

Verstraete W, Philips S. 1998. Nitrification-denitrification processes and technologies in new contexts. Environ Pollut 102(1):717-726.

Volcke EIP, Picioreanu C, De Baets B, van Loosdrecht MCM 2012. The granule size distribution in an anammox-based granular sludge reactor affects the conversion-Implications for modeling. Biotechnol Bioeng 109:1629-1636.

Wertz S, Poly F, Le Roux X, Degrange V. 2008. Development and application of a PCR-denaturing gradient gel electrophoresis tool to study the diversity of Nitrobacter-like nxrA sequences in soil. FEMS Microbiol Ecol 63(2):261-271.

Wiesmann U. 1994. Biological nitrogen removal from wastewater. In: Fiechter A, editor. Advances in Biochemical Engineering/Biotechnology. Berlin: Springer-Verlag Berlin Heidelberg. p 113154.

Winkler MK, Bassin JP, Kleerebezem R, Sorokin DY, van Loosdrecht MC. 2012. Unravelling the reasons for disproportion in the ratio of $\mathrm{AOB}$ and NOB in aerobic granular sludge. Appl Microbiol Biotechnol 94(6):1657-1666.

Winkler MK, Kleerebezem R, de Bruin LMM, Verheijen PJT, Abbas B, Habermacher J, van Loosdrecht MCM. 2013. Microbial diversity differences within aerobic granular sludge and activated sludge flocs. Appl Microbiol Biotechnol 97(16):7447-7458.

Wittebolle L, Vervaeren H, Verstraete W, Boon N. 2008. Quantifying community dynamics of nitrifiers in functionally stable reactors. Appl Environ Microbiol 74(1):286-293.

Xu H, Wang C, Liang Z, He L, Wu W. 2015. The structure and component characteristics of partial nitrification biofilms under autotrophic and heterotrophic conditions. Appl Microbiol Biotechnol 99(8):3673-83.

Yuan Z, Blackall LL. 2002. Sludge population optimisation: a new dimension for the control of biological wastewater treatment systems. Water Res 36(2):482-90.

This article is protected by copyright All rights reserved nitrifying biofilm reactor: Correlation analysis and simulation study. Biotechnology and 


\section{List of Tables}

Table 1 Standard curve parameters for the qPCR-analysis.

Table 2 Overview of the simulation set-up. In Approach 3, the two AOB and NOB populations are based on the calibrated values for period A and B from Approach 2.

Table 3 Periods distinguished during continuous operation (592 days) of the nitrifying reactor (Bougard et al. 2006b). NLR: nitrogen loading rate and $\mathrm{Q}_{\text {in: }}$ liquid flow rate.

Table 4 Correlation matrix for the chemical and physical data (291 observations, DO 290 observations), including correlation coefficients $r$ and $p$-values. Correlations with a $p$-value smaller than 0.05 are in bold.

Table 5 Correlation matrix between data on the process conditions and the microbial community $(n=28)$, including correlation coefficients $r$ and $p$-values. Bold values refer to significant correlations ( $\mathrm{p}$-value $<0.05)$.

Table 6 Constraints and calibrated microbial parameters values for $\mathrm{AOB}$ and $\mathrm{NOB}$ at $30^{\circ} \mathrm{C}$ and $\mathrm{pH}$ 7.5 when two periods were calibrated, i.e., Period A: day 0-100 and Period B: day 100-592 (Approach 2). The calibrated values should be carefully interpreted, as the uncertainty of the estimated values was not verified.

This article is protected by copyright All rights reserved 


\section{List of Figures}

Figure 1 Macroscopic and microscopic dynamic behaviour of the inverse turbulent bed reactor: (A) Bulk liquid concentrations of total ammonium $(\mathrm{TNH})$, total nitrite $\left(\mathrm{TNO}_{2}\right)$ and nitrate, taken from Bougard et al. (2006b), (B) the corresponding free ammonia (FA) and free nitrous acid (FNA) concentrations, calculated based on reactor temperature and $\mathrm{pH}$ (Anthonisen et al. 1976), (C) the percentage of AOB and NOB in the microbial community, based on qPCR-analysis and (D) the diversity of the microbial community, analysed using CE-SSCP and expressed as the negative logarithm of the Simpson index, $\mathrm{D}_{\mathrm{SSCP}}$. The roman numbers denote the different periods distinguished (Table 3). Note the difference scales of the $\mathrm{y}$-axes in plot B and C.

Figure 2 Boxplots representing the reported ranges for inhibition constants for FA ( $\mathrm{K}_{\mathrm{I}, \mathrm{FA}}$, left) and FNA ( $\mathrm{K}_{\mathrm{I}, \mathrm{FNA}}$, right) of $\mathrm{AOB}$ (top) and NOB (bottom) found in literature. Max = maximum value found in literature, $\mathrm{Q} 3=$ third quartile, $\mathrm{M}=$ median, $\mathrm{Q} 1=$ first quartile and $\min =$ minimum value. The raw data of the literature review can be found in the Supplementary Information (Table S.4). It should be noted that FA inhibition of AOB and FNA inhibition of NOB is generally described by a Haldane term, while FNA inhibition of AOB and FA inhibition of NOB is described with a noncompetitive inhibition term.

Figure 3 Simulation of the macroscopic reactor behaviour observed during reactor operation using the calibrated 1-dimensional biofilm model considering growth and decay of $1 \mathrm{AOB}$ and $1 \mathrm{NOB}$ species, besides heterotrophs: (A) Approach 1, (B) Approach 2, Period A and (C) Approach 2, Period B. The roman numbers denote the different periods distinguished (Table 3).

This article is protected by copyright All rights reserved nitrifying biofilm reactor: Correlation analysis and simulation study. Biotechnology and 
Table 1 Standard curve parameters for the qPCR-analysis.

\begin{tabular}{l|ccc}
\hline & $\begin{array}{c}\text { Total bacterial } \\
\text { community }\end{array}$ & AOB & NOB \\
\hline Fluorophore & Yakima Yellow & FAM & SybrGreen \\
Slope & -3.342 & -3.369 & -3.310 \\
Y-intercept & 42.93 & 43.16 & 35.27 \\
Efficiency & 0.99 & 0.98 & 1.00 \\
$\mathbf{R}^{2}$ & 0.970 & 0.998 & 0.993 \\
\hline
\end{tabular}

This article is protected by copyright All rights reserved 
Table 2 Overview of the simulation set-up. In Approach 3, the two AOB and NOB populations are based on the calibrated values for period A and B from Approach 2.

\begin{tabular}{|c|c|c|}
\hline Approach & Period calibrated (days) & Nitrifying community (calibrated) \\
\hline 1 & $0-592$ & $1 \mathrm{AOB}+1 \mathrm{NOB}$ \\
\hline 2 & $\begin{array}{c}\text { Period A: } 0-100 \\
\text { Period B: } 100-592\end{array}$ & $1 \mathrm{AOB}+1 \mathrm{NOB}$ \\
\hline 3 & $0-592$ & $2 \mathrm{AOB}+2 \mathrm{NOB}$ \\
\hline
\end{tabular}

This article is protected by copyright All rights reserved 
Table 3 Periods distinguished during continuous operation (592 days) of the nitrifying reactor (Bougard et al. 2006b). NLR: nitrogen loading rate and $\mathrm{Q}_{\text {in: liquid flow rate. }}$

\begin{tabular}{|c|c|c|c|c|c|}
\hline Period & Days & $\begin{array}{c}\text { Dominant } \\
\text { AOB }\end{array}$ & $\begin{array}{c}\text { Temperature } \\
\left({ }^{\circ} \mathbf{C}\right)\end{array}$ & $\begin{array}{c}\text { Control } \\
\text { strategies }\end{array}$ & $\begin{array}{c}\text { Process } \\
\text { performance }\end{array}$ \\
\hline \multirow[b]{2}{*}{ I } & $0-50$ & N. halophila & \multirow[b]{2}{*}{30} & \multirow{2}{*}{ D. } & \multirow{2}{*}{$\begin{array}{c}\mathrm{NO}_{3}^{-} \\
\text {accumulation }\end{array}$} \\
\hline & $51-113$ & $\begin{array}{l}\text { N. halophila } \\
\text { N. europaea }\end{array}$ & & & \\
\hline II & $114-230$ & N. europaea & $30 \rightarrow 35$ & $\begin{array}{c}\text { Temperature } \\
\text { control }\end{array}$ & $\begin{array}{c}\mathrm{NO}_{2}^{-} \\
\text {accumulation }\end{array}$ \\
\hline III & 231-491 & N. europaea & 30 & Lowering $Q_{\text {in }}$ & $\begin{array}{l}\text { Shift from } \\
\mathrm{NO}_{2}^{-} \text {to } \mathrm{NO}_{3}^{-} \\
\text {accumulation }\end{array}$ \\
\hline IV & $492-592$ & N. europaea & 30 & $\begin{array}{l}\text { Fuzzy logic } \\
\text { DO/ammonium } \\
\text { control by } \\
\text { adjusting } \mathrm{Q}_{\text {in }} \\
\text { (and thus NLR) }\end{array}$ & $\begin{array}{c}\mathrm{NO}_{2}^{-} \\
\text {accumulation }\end{array}$ \\
\hline
\end{tabular}

This article is protected by eopyright All rights reserved

Vannecke, T.P. Bernet, N. Winkler. M. K. Santa-Catalina, G. Steyer, J.-P. Volcke, E. I. 
Table 4 Correlation matrix for the chemical and physical data (291 observations, DO 290 observations), including correlation coefficients $r$ and $p$-values. Correlations with a $p$-value smaller than 0.05 are in bold.

\begin{tabular}{|c|c|c|c|c|c|c|c|c|c|}
\hline $\begin{array}{l}\mathrm{TNO}_{2} \\
\left(\mathrm{~g} \mathrm{TNO}_{2}-\mathrm{NN}^{-3}\right)^{-3}\end{array}$ & $\begin{array}{l}0.08 \\
(0.2)\end{array}$ & & & & & & & & \\
\hline $\begin{array}{l}\mathrm{NO}_{3} \\
\left(\mathrm{~g} \mathrm{NO}_{3}-\mathrm{N} \cdot \mathrm{m}^{-3}\right)\end{array}$ & $\begin{array}{c}-0.22 \\
(p<0.01)\end{array}$ & $\begin{array}{c}-0.88 \\
(p<0.01)\end{array}$ & & & & & & & \\
\hline $\begin{array}{l}\text { FA } \\
\left(\mathrm{g} \mathrm{NH}_{3}-\mathrm{N}^{-} \cdot \mathrm{m}^{-3}\right)\end{array}$ & $\begin{array}{c}0.68 \\
(p<0.01)\end{array}$ & $\begin{array}{l}-0.05 \\
(0.35)\end{array}$ & $\begin{array}{l}-0.11 \\
(0.07)\end{array}$ & & & & & & \\
\hline $\begin{array}{l}\text { FNA } \\
\left(\mathrm{g} \mathrm{HNO}_{2}-\mathrm{N}^{-m^{-3}}\right)\end{array}$ & $\begin{array}{c}-0.06 \\
(0.33)\end{array}$ & $\begin{array}{c}0.95 \\
(p<0.01)\end{array}$ & $\begin{array}{c}-0.82 \\
(p<0.01)\end{array}$ & $\begin{array}{c}-0.14 \\
(0.02)\end{array}$ & & & & & \\
\hline $\begin{array}{l}\text { Temperature } \\
\left({ }^{\circ} \mathbf{C}\right)\end{array}$ & $\begin{array}{c}0.26 \\
(p<0.01)\end{array}$ & $\begin{array}{c}0.32 \\
(p<0.01)\end{array}$ & $\begin{array}{c}-0.39 \\
(p<0.01)\end{array}$ & $\begin{array}{c}0.05 \\
(0.35)\end{array}$ & $\begin{array}{c}0.3 \\
(p<0.01)\end{array}$ & & & & \\
\hline $\begin{array}{l}\text { DO } \\
\left(\mathrm{g} \mathrm{O}_{2} \cdot \mathrm{m}^{-3}\right)\end{array}$ & $\begin{array}{c}-0.21 \\
(p<0.01)\end{array}$ & $\begin{array}{l}-0.03 \\
(0.63) \\
\end{array}$ & $\begin{array}{l}-0.02 \\
(0.69) \\
\end{array}$ & $\begin{array}{l}-0.09 \\
(0.14) \\
\end{array}$ & $\begin{array}{c}0.02 \\
(0.72) \\
\end{array}$ & $\begin{array}{l}-0.02 \\
(0.69) \\
\end{array}$ & & & \\
\hline pH & $\begin{array}{c}0.6 \\
(p<0.01)\end{array}$ & $\begin{array}{c}-0.13 \\
(0.02)\end{array}$ & $\begin{array}{c}-0.11 \\
(0.07)\end{array}$ & $\begin{array}{c}0.74 \\
(p<0.01)\end{array}$ & $\begin{array}{c}-0.29 \\
(p<0.01)\end{array}$ & $\begin{array}{l}-0.01 \\
(0.91)\end{array}$ & $\begin{array}{l}-0.07 \\
(0.24)\end{array}$ & & \\
\hline $\begin{array}{l}\text { NLR } \\
\left(\mathrm{g} \mathrm{N}^{-m^{-3}} \cdot \mathrm{d}^{-1}\right)\end{array}$ & $\begin{array}{c}0.26 \\
(p<0.01)\end{array}$ & $\begin{array}{c}-0.09 \\
(0.13)\end{array}$ & $\begin{array}{c}0.14 \\
(0.02)\end{array}$ & $\begin{array}{l}0.16 \\
(0.01)\end{array}$ & $\begin{array}{l}-0.13 \\
(0.03)\end{array}$ & $\begin{array}{l}-0.01 \\
(0.89)\end{array}$ & $\begin{array}{c}-0.45 \\
(p<0.01)\end{array}$ & $\begin{array}{c}0.08 \\
(0.15)\end{array}$ & \\
\hline \multirow[t]{2}{*}{$\begin{array}{l}\text { C/N-ratio } \\
(\text { g COD.gN }\end{array}$} & $\begin{array}{c}-0.27 \\
(p<0.01)\end{array}$ & $\begin{array}{c}-0.33 \\
(p<0.01)\end{array}$ & $\begin{array}{c}0.14 \\
(0.02)\end{array}$ & $\begin{array}{c}-0.13 \\
(0.03)\end{array}$ & $\begin{array}{c}-0.29 \\
(p<0.01)\end{array}$ & $\begin{array}{c}-0.26 \\
(p<0.01)\end{array}$ & $\begin{array}{c}0.53 \\
(p<0.01)\end{array}$ & $\begin{array}{l}-0.08 \\
(0.19)\end{array}$ & $\begin{array}{c}-0.25 \\
(p<0.01)\end{array}$ \\
\hline & $\begin{array}{c}\text { TNH } \\
\left(\mathrm{g} \text { TNH-N.m }{ }^{-3}\right) \\
\end{array}$ & $\begin{array}{c}\mathrm{TNO}_{2} \\
\left(\mathrm{~g} \mathrm{TNO}_{2}-\mathrm{N}^{-3} \mathrm{~m}^{-3}\right)\end{array}$ & $\begin{array}{c}\mathrm{NO}_{3} \\
\left(\mathrm{~g} \mathrm{NO}_{3}-\mathrm{N} \cdot \mathrm{m}^{-3}\right) \\
\end{array}$ & $\begin{array}{c}\text { FA } \\
\left(\mathrm{g} \mathrm{NH}_{3}-\mathrm{N} \cdot \mathrm{m}^{-3}\right) \\
\end{array}$ & $\begin{array}{c}\text { FNA } \\
\left(\mathrm{g} \mathrm{HNO}_{2}-\mathrm{N} \cdot \mathrm{m}^{-3}\right) \\
\end{array}$ & $\begin{array}{c}\text { Temperature } \\
\left({ }^{\circ} \mathbf{C}\right)\end{array}$ & $\begin{array}{c}\text { DO } \\
\left(\mathrm{g} \mathrm{O}_{2} \cdot \mathrm{m}^{-3}\right) \\
\end{array}$ & $\mathrm{pH}$ & 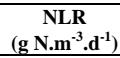 \\
\hline
\end{tabular}

This article is protected by copyright All rights reserved

Vannecke, T. P., Bernet, N. Winkler, M. K., Santa-Catalina, G., Steyer, J.-P. Volcke. E. I. 
Table 5 Correlation matrix between data on the process conditions and the microbial community $(\mathrm{n}=28)$, including correlation coefficients $\mathrm{r}$ and $\mathrm{p}$-values. Bold values refer to significant correlations ( $\mathrm{p}$-value $<0.05$ ).

\begin{tabular}{|c|c|c|c|c|c|}
\hline & $\begin{array}{c}\text { Fraction AOB } \\
(\%)\end{array}$ & $\begin{array}{c}\text { Fraction NOB } \\
(\%) \\
\end{array}$ & $\begin{array}{l}\text { Diversity total } \\
\text { community } \\
\left(D^{\prime}\right)\end{array}$ & $\begin{array}{c}\text { AOB diversity } \\
\text { (D') }\end{array}$ & $\begin{array}{c}\text { NOB diversity } \\
\left(D^{\prime}\right)\end{array}$ \\
\hline $\begin{array}{l}\text { TNH } \\
(\mathrm{g} \text { TNH-N.m-3 })\end{array}$ & $0.07(0.71)$ & $-0.34(0.07)$ & $-0.12(0.53)$ & $0.1(0.6)$ & $-0.16(0.39)$ \\
\hline $\begin{array}{l}\mathrm{TNO}_{2} \\
\left(\mathrm{~g} \mathrm{TNO}_{2}-\mathrm{N}^{-m^{-3}}\right) \\
\end{array}$ & $0.63(p<0.01)$ & $-0.78(p<0.01)$ & $-0.45(0.01)$ & $-0.22(0.24)$ & $0.04(0.83)$ \\
\hline $\begin{array}{l}\mathrm{NO}_{3} \\
\left(\mathrm{~g} \mathrm{NO}_{3}-\mathrm{N} \cdot \mathrm{m}^{-3}\right)\end{array}$ & $-0.57(p<0.01)$ & $0.72(p<0.01)$ & $0.24(0.19)$ & $0.27(0.16)$ & $0.2(0.29)$ \\
\hline $\begin{array}{l}\text { FA } \\
\left(\mathrm{g} \mathrm{NH}_{3}-\mathrm{N}^{-} \mathrm{m}^{-3}\right)\end{array}$ & $-0.07(0.7)$ & $-0.2(0.3)$ & $0.07(0.72)$ & $-0.01(0.96)$ & $-0.27(0.14)$ \\
\hline $\begin{array}{l}\text { FNA } \\
\left.\left(\mathrm{g} \mathrm{HNO}_{2}-\mathrm{N}^{-3}\right)^{-3}\right)\end{array}$ & $0.64(p<0.01)$ & $-0.73(p<0.01)$ & $-0.48(0.01)$ & $-0.26(0.16)$ & $-0.02(0.91)$ \\
\hline $\begin{array}{l}\text { Temperature } \\
\left({ }^{\circ} \mathrm{C}\right)\end{array}$ & $0.28(0.13)$ & $-0.34(0.07)$ & $0.06(0.77)$ & $-0.14(0.45)$ & $-0.36(0.05)$ \\
\hline $\begin{array}{l}\text { DO } \\
\left(\mathrm{g} \mathrm{O}_{2} \cdot \mathrm{m}^{-3}\right) \\
\end{array}$ & $0.04(0.85)$ & $-0.02(0.9)$ & $0.13(0.48)$ & $-0.29(0.11)$ & $0.18(0.34)$ \\
\hline $\mathbf{p H}$ & $-0.09(0.64)$ & $-0.1(0.6)$ & $0.2(0.3)$ & $0.13(0.49)$ & $-0.27(0.15)$ \\
\hline $\begin{array}{l}\text { NLR } \\
\left(\mathrm{g} \mathrm{N}^{-3} \mathrm{~m}^{-3} \cdot \mathrm{d}^{-1}\right) \\
\end{array}$ & $0.14(0.45)$ & $0.1(0.59)$ & $0.07(0.71)$ & $0.42(0.02)$ & $-0.02(0.93)$ \\
\hline $\begin{array}{l}\text { C/N-ratio } \\
(\mathrm{g} \text { COD.g N }\end{array}$ & $-0.19(0.31)$ & $0.3(0.1)$ & $0.33(0.07)$ & $-0.06(0.76)$ & $0.22(0.25)$ \\
\hline $\begin{array}{l}\text { Fraction AOB } \\
(\%)\end{array}$ & & $-0.47(0.01)$ & $-0.39(0.04)$ & $-0.41(0.02)$ & $-0.09(0.65)$ \\
\hline $\begin{array}{l}\text { Fraction NOB } \\
(\%)\end{array}$ & & & $0.53(p<0.01)$ & $0.22(0.25)$ & $-0.07(0.71)$ \\
\hline $\begin{array}{l}\text { Diversity total } \\
\text { community } \\
\text { (D } \\
\text { (DSCP) }\end{array}$ & & & & $0.28(0.14)$ & $0.03(0.88)$ \\
\hline $\begin{array}{l}\text { AOB diversity } \\
\left(\mathrm{D}_{\mathrm{SSCP}}\right)\end{array}$ & & & & & $0.18(0.35)$ \\
\hline $\begin{array}{l}\text { NOB diversity } \\
\left(\mathrm{D}_{\mathrm{SSCP}}\right)\end{array}$ & & & & & \\
\hline
\end{tabular}

This article is protected by copyright All rights reserved

Vannecke, T. P., Bernet, N.. Winkler, M. K., Santa-Catalina, G., Steyer, J.-P., Volcke, E. I. 
Table 6 Constraints and calibrated microbial parameters values for $\mathrm{AOB}$ and $\mathrm{NOB}$ at $30{ }^{\circ} \mathrm{C}$ and $\mathrm{pH}$ 7.5 when two periods were calibrated, i.e., Period A: day 0-100 and Period B: day 100-592 (Approach 2). The calibrated values should be carefully interpreted, as the uncertainty of the estimated values was not verified.

\begin{tabular}{|c|c|c|c|c|c|c|}
\hline & & $\begin{array}{c}\text { Starting } \\
\text { (median) value }\end{array}$ & Minimum value & $\begin{array}{c}\text { Maximum } \\
\text { value }\end{array}$ & $\begin{array}{c}\text { Calibrated value } \\
\text { Period A } \\
\end{array}$ & $\begin{array}{c}\text { Calibrated value } \\
\text { Period B } \\
\end{array}$ \\
\hline $\mathbf{K}_{\mathrm{I}, \mathrm{FA}}^{\mathrm{AOB}}$ & g FA-N.m ${ }^{-3}$ & 64.25 & 5.80 & 3000 & 490.51 & 489.05 \\
\hline $\mathbf{K}_{\mathbf{I}, \mathbf{F A}}^{\mathrm{NOB}}$ & g FA-N.m ${ }^{-3}$ & 2.52 & 0.43 & 20 & 12.93 & 10.06 \\
\hline $\mathbf{K}_{\mathrm{I}, \mathrm{FNA}}^{\mathrm{AOB}}$ & g FNA-N. $\mathrm{m}^{-3}$ & 0.21 & 0.05 & 2.80 & 0.42 & 0.21 \\
\hline $\mathbf{K}_{\mathrm{I}, \mathrm{FNA}}^{\mathrm{NOB}}$ & g FNA-N.m ${ }^{-3}$ & 0.12 & 0.02 & 2.80 & 0.27 & 0.13 \\
\hline $\mathbf{K}_{\mathrm{FA}}^{\mathrm{AOB}}$ & g FA-N.m $\mathrm{m}^{-3}$ & 0.23 & 0.0018 & 1.29 & 1.25 & 1.29 \\
\hline $\mathbf{K}_{\mathrm{FNA}}^{\mathrm{NOB}}$ & g FNA-N.m ${ }^{-3}$ & $1.04 \mathrm{e}-004$ & $3.12 \mathrm{e}-006$ & $2.41 \mathrm{e}-003$ & 0.0015 & 0.0024 \\
\hline $\mathbf{K}_{02}^{\mathrm{AOB}}$ & $\mathrm{g} \mathrm{O}_{2} \cdot \mathrm{m}^{-3}$ & 0.40 & 0.07 & 3 & 0.078 & 0.71 \\
\hline $\mathrm{K}_{\mathrm{O} 2}^{\mathrm{NOB}}$ & $\mathrm{g} \mathrm{O}_{2} \cdot \mathrm{m}^{-3}$ & 0.97 & 0.04 & 4.01 & 0.049 & 0.06 \\
\hline$\mu_{\max }^{\mathrm{AOB}}$ & $d^{-1}$ & 1.34 & 0.33 & 3.40 & 0.65 & 0.71 \\
\hline$\mu_{\max }^{\mathrm{NOB}}$ & $d^{-1}$ & 1 & 0.24 & 3.54 & 1.43 & 0.30 \\
\hline $\mathbf{b}_{\mathrm{AOB}}$ & $\mathrm{d}^{-1}$ & 0.067 & 0.017 & 0.17 & 0.073 & 0.061 \\
\hline $\mathbf{b}_{\mathrm{NOB}}$ & $d^{-1}$ & 0.05 & 0.012 & 0.18 & 0.13 & 0.051 \\
\hline
\end{tabular}

This article is protected by copyright All rights reserved

Vannecke, T. P., Bernet, N., Winkler, M. K., Santa-Catalina, G., Steyer, J.-P., Volcke. E. I. 



Figure 1

This article is protected by copyright All rights reserved 


\section{$\mathrm{AOB}$}
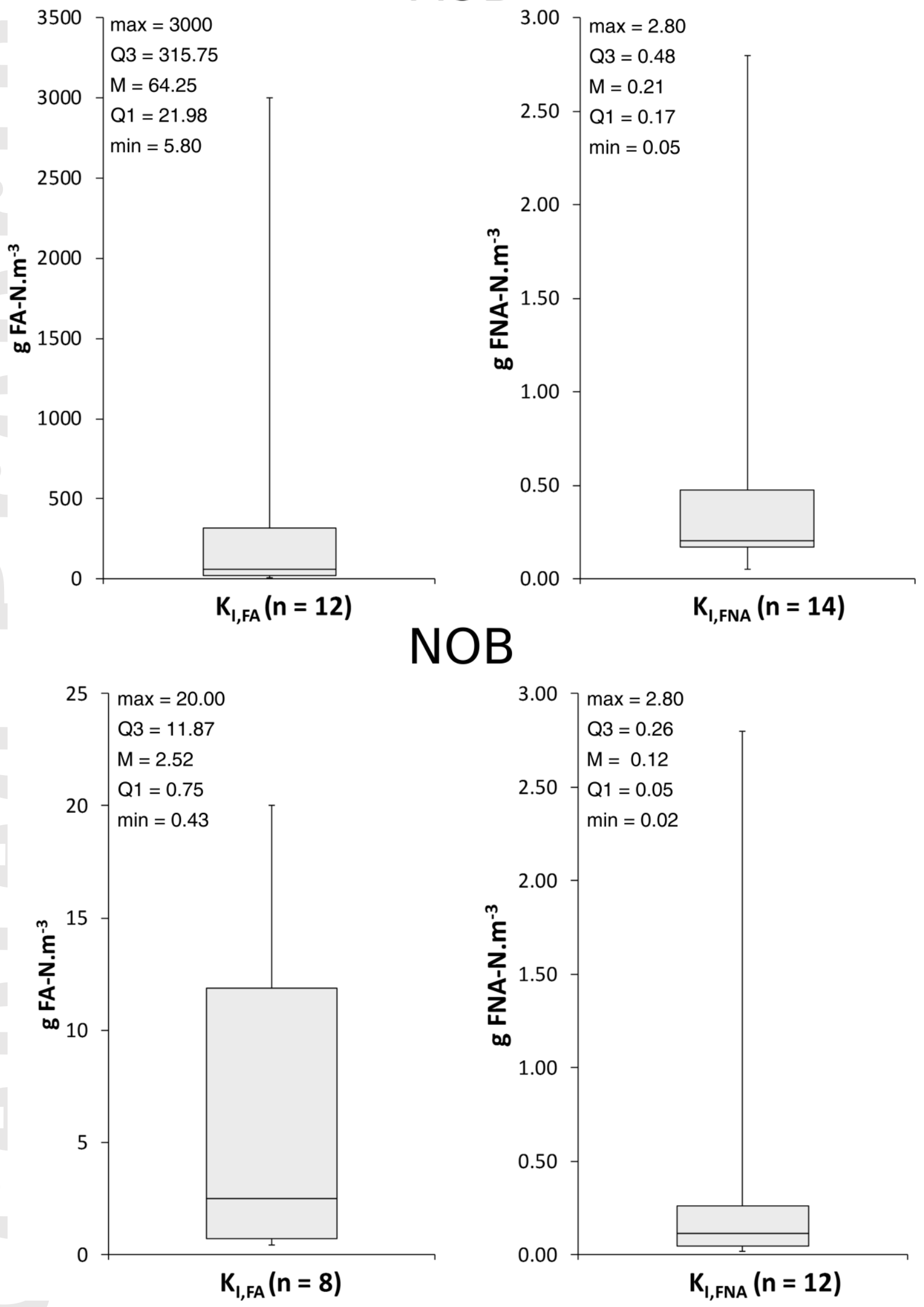

Figure 2

This article is protected by copyright All rights reserved 
A

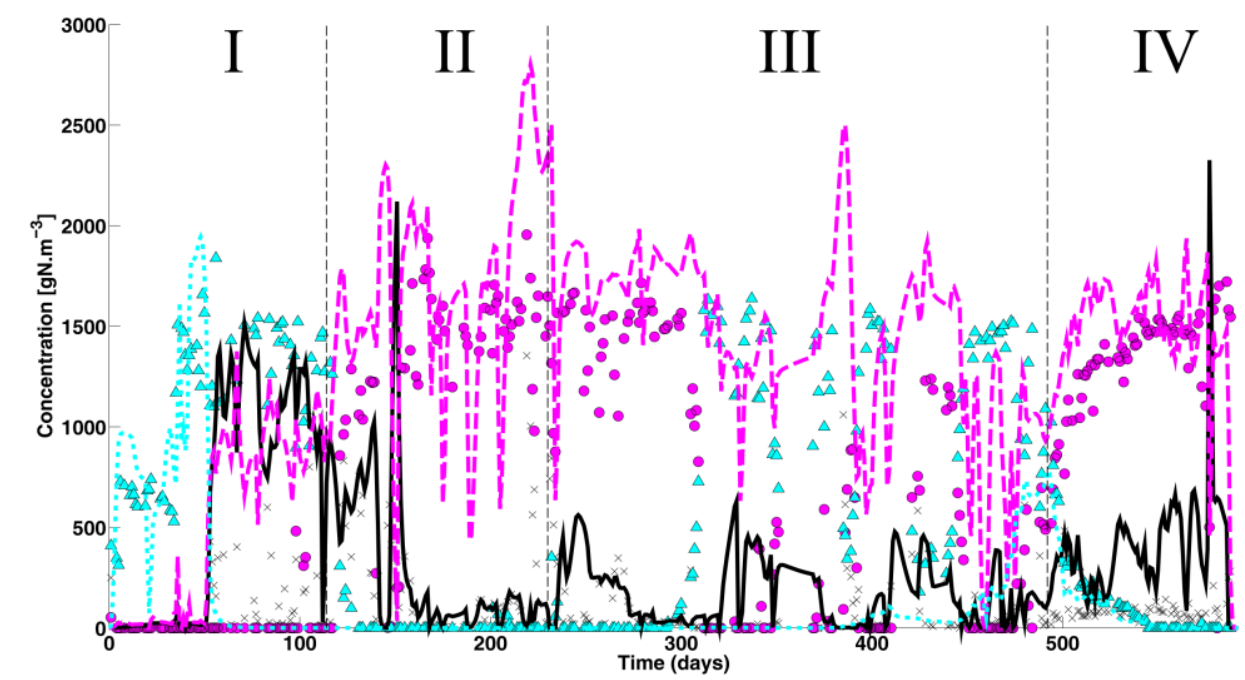

$\mathrm{TNH}-\mathrm{N}(\exp ) \bullet \mathrm{TNO}_{2}-\mathrm{N}(\exp ) \triangle \mathrm{NO}_{3}-\mathrm{N}(\exp )-\mathrm{TNH}-\mathrm{N}(\operatorname{sim})--\mathrm{TNO}_{2}-\mathrm{N}(\operatorname{sim})=-\mathrm{NO}_{3}-\mathrm{N}(\operatorname{sim})$

B

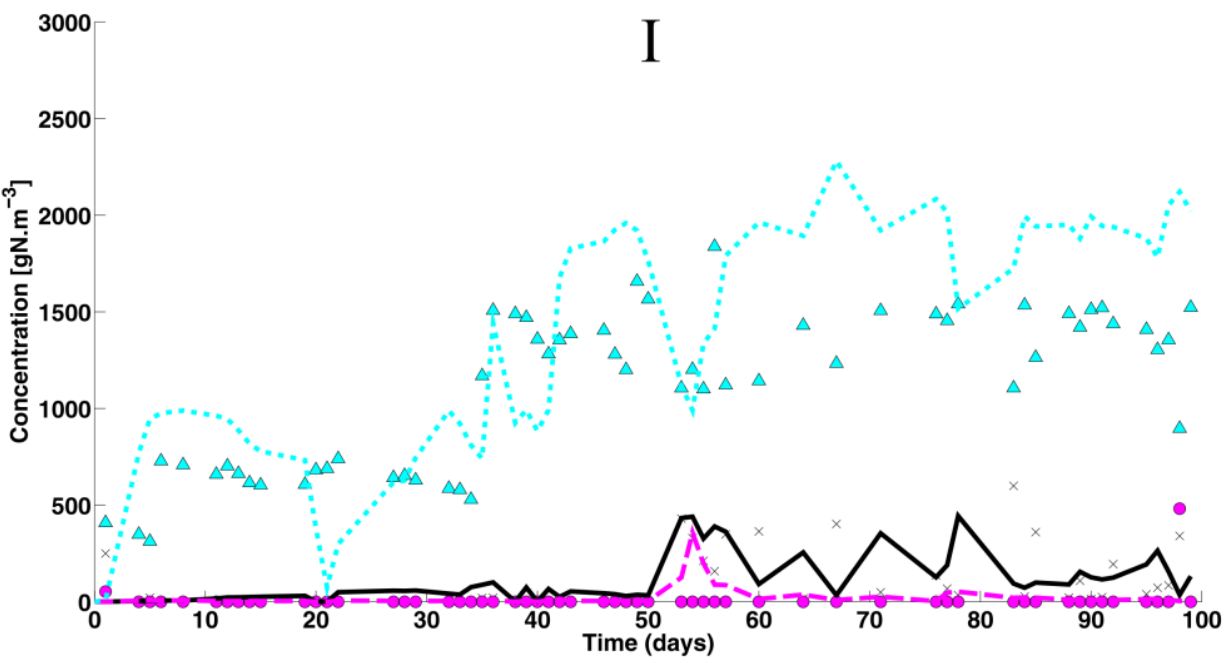

$\times \mathrm{TNH}-\mathrm{N}(\exp ) \bullet \mathrm{TNO}_{2}-\mathrm{N}(\exp ) \triangle \mathrm{NO}_{3}-\mathrm{N}(\exp )-\mathrm{TNH}-\mathrm{N}(\operatorname{sim})--\mathrm{TNO}_{2}-\mathrm{N}(\operatorname{sim}) \ldots \mathrm{NO}_{3}-\mathrm{N}(\operatorname{sim})$

C

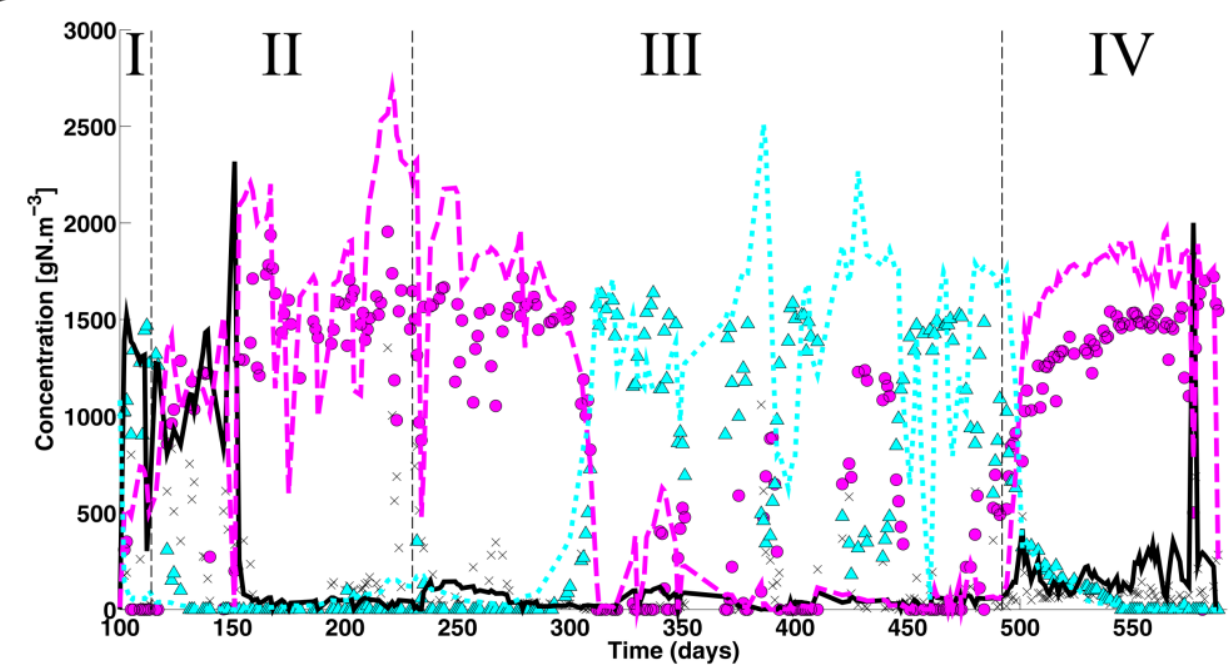

$\mathrm{TNH}-\mathrm{N}(\exp ) \bullet \mathrm{TNO}_{2}-\mathrm{N}(\exp ) \Delta \mathrm{NO}_{3}-\mathrm{N}(\exp )-\mathrm{TNH}-\mathrm{N}(\operatorname{sim})--\mathrm{TNO}_{2}-\mathrm{N}(\operatorname{sim}) \ldots \mathrm{NO}_{3}-\mathrm{N}(\operatorname{sim})$

Figure 3

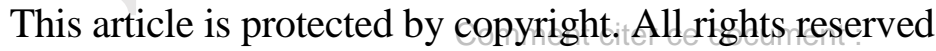

